\title{
Double Acid-Base Extraction of Silicic Acid from Quartz Sand
}

\author{
Laksmita Prima Santi1 ${ }^{1}$ Djoko Mulyanto², Didiek Hadjar Goenadi ${ }^{1}$ \\ ${ }^{1}$ Indonesian Research Institute for Biotechnology and Bioindustry, Bogor, Indonesia \\ ${ }^{2}$ Pembangunan Nasional Yogyakarta University, Yogyakarta, Indonesia \\ Email: laksmita.santi@gmail.com
}

How to cite this paper: Santi, L.P., Mulyanto, D. and Goenadi, D.H. (2017) Double Acid-Base Extraction of Silicic Acid from Quartz Sand. Journal of Minerals and Materials Characterization and Engineering, 5, 362-373.

https://doi.org/10.4236/jmmce.2017.56030

Received: September 9, 2017

Accepted: November 12, 2017

Published: November 15, 2017

Copyright $\odot 2017$ by authors and Scientific Research Publishing Inc. This work is licensed under the Creative Commons Attribution International License (CC BY 4.0).

http://creativecommons.org/licenses/by/4.0/

(c) (i) Open Access

\begin{abstract}
Silica is becoming more attractive as plant nutrient for non-graminae crops particularly in relation with drought-stress tolerant. Many efforts have been conducted to obtain an efficient technique to produce silica fertilizer worldwide, but the results are varying considerably due to various factors including raw material and extraction technique. This study was carried out to develop an efficient extraction technique for ortho-silicic acid $\left(\mathrm{OSA}-\mathrm{H}_{4} \mathrm{SiO}_{4}\right)$ from a Bangka-Belitung quartz sand by employing acid-base dissolution method. A 325 -mesh size quartz sand was boiled in $\mathrm{HCl}$ solution at various concentrations. The optimum concentration was then used in the following experiment at several different volumes of solution. The sand obtained from optimum concentration and volume of $\mathrm{HCl}$ solution was then reacted with different amounts of $\mathrm{NaOH}(\mathrm{s})$, and heated until a wet mixture was obtained. As a reference the best extraction conditions were applied to a natural zeolite sample. All OSA analyses were done in triplicates with spectrophotometric method. Supporting evidences were collected from $x$-ray diffraction and scanning-electron-microscopy analyses of the treated samples. The yield of quartz sand-originated OSA was $183 \mathrm{~g} \cdot \mathrm{kg}^{-1}$ and significantly increased linearly with increasing weight of $\mathrm{NaOH}\left(\mathrm{R}^{2}=0.99^{* *}\right)$, whereas that from zeolite was only $104.2 \mathrm{~g} \cdot \mathrm{kg}^{-1}$ at $80 \mathrm{~g} \mathrm{NaOH}$. XRD and SEM data confirmed the evidences that the acid-base extraction disrupted the quartz mineral structure and as a consequence releasing more water soluble OSA.
\end{abstract}

\section{Keywords}

Ortho-Silicic Acid, Bangka-Belitung Quartz Sand, Acid-Base Dissolution, Pre-Washed

\section{Introduction}

Silicon is abundant in soil, but most of its sources are not available for plant up- 
take due to low solubility of Si compounds in soil [1] [2]. Although it is not accepted as one of essential plant nutrients, many evidences have shown strategic function of silica $(\mathrm{Si})$ in crop cultivation i.e. stimulate nutrient uptake and plant photosynthesis, decrease susceptibility to disease and insect damage, alleviate water and various mineral stresses and decrease the toxic effects of aluminum [3] [4] [5]. Reference [6] stated that plants absorb Si as much as some other macro essential nutrients. Some evidences indicate that $\mathrm{Si}$ application to soil can improve phosphate $(\mathrm{P})$ uptake by plants as $\mathrm{Si}$ will compete to get aluminum (Al) and/or iron $(\mathrm{Fe})$ and releasing $\mathrm{P}$ as a result. These are some reasons why the use of $\mathrm{Si}$ will become highly potential to be a fundamental element in supporting sustainable agriculture, biological/organic production, and environment protection [7]. Silicon in the soil solution usually in different forms and occurs primarily as monomeric i.e. ortho-silicic acid (OSA). This monomer is up taken by plant [8] and mostly resides in the cell walls. This will then, to some extent, be considered to be responsible in controlling stomatal activities especially when the plant face drought stress [9] [10]. Reference [11] observed that Si addition to soils will not only improve chlorophyll content but also chlorophyll a/b ratio. There was a linier relationship between chlorophyll a/b ratio and photosynthesis impedance.

$\mathrm{Si}$ is the second abundant element $(27.7 \% \mathrm{w} / \mathrm{w})$ after oxygen $(47 \% \mathrm{w} / \mathrm{w})$ in soils [12]. Si compounds mainly present as $\mathrm{SiO}_{2}$, about $50 \%-70 \%$ of the soil mass, and in various aluminosilicate forms [13]. However, most of the $\mathrm{Si}$ in soils is found in insoluble forms. It is well known that $\mathrm{Si}$ absorption could be insoluble form i.e. OSA $\left(\mathrm{H}_{4} \mathrm{SiO}_{4}\right)$. Its solubility was reported depending on particle size of the bearing mineral [14]. In soil, silicon is generally grouped into three different fractions such as the solid phase, the liquid phase and the adsorbed phase [15]. The crystalline form consisted only of the primary and the secondary crystalline silicates, which are abundant in mineral soils that developed from rocks and sediments [16]. The silica materials consist primarily of quartz and disordered silica. The amorphous and poorly crystalline and microcrystalline forms are also components of the silicon fractions in the solid phase [17]. The components of silicon in the liquid and the adsorbed phases are similar, with exception that those in liquid phase are dissolved in the soil solution, whereas those that are adsorbed are held onto soil particles and the $\mathrm{Fe}$ and $\mathrm{Al}$ oxides/hydroxides.

In soil, Si compounds exist in two forms viz. liquid and solid. The solid form mainly consists of crystalline, poorly crystalline, and amorphous silica (ASi) [15]. The liquid form generally consists of mono- and polysilicic acids, complexed with organic and inorganic compounds, etc. [18]. Wollastonite is a naturally occurring mined $\mathrm{CaSiO}_{3}$ and can be a useful $\mathrm{Si}$ source when finely ground. However, this mineral is not found in Indonesia. Bangka-Belitung province is the largest deposit and has best quality of quartz in Indonesia, therefore can be used as locally sources for silicate fertilizer. Quartz is the second most abundant mineral in Earth's continental crust, after feldspar. Quartz is a compound of 
one-part silicon and two parts of oxygen, silicon dioxide, $\mathrm{SiO}_{2}$. The specific objective of this study was to justify the assumption that a locally-abundant quartz sand is suitable as an efficient raw material to produce Si fertilizer by using a double $\mathrm{HCl}-\mathrm{NaOH}$ extraction technique in Indonesia.

\section{Material and Method}

\subsection{Silica Sources}

A 325-mesh quartz sand commercial sample was originated from Bangka-Belitung province, Indonesia (Figure 1). The area has highly unique geological landscape as it was derived from metamorphic rocks with granitic intrusion including tin-consisting granite and granodiorite [19]. Other geological formations are also found consisting of metamorphic alluvial sandstone, mud deposit with sandstone lenses, and quartzite [20]. Biotite Granites rock found are rich in silica (average $717.8 \mathrm{~g} \cdot \mathrm{kg}^{-1} \mathrm{SiO}_{2}$ ), coarse grained, commonly porphyrite and sometimes foliated. Hornblende-Biotite Granodiorites are, medium to coarse grained, sometimes porphyritic and usually non-foliated. The Middle Triassic Tanjung Pandan batholith on Belitung Island is associated with major alluvial tin deposits and with minor primary tin mineralization of greisen type (Tikus Mine). Sub economic quartz-tourmaline-cassiterite veinlets and stock works are locally abundant. The batholith consists of two petrogenetically different, ilmenite-series rock suites with about the same age of $215 \pm 3 \mathrm{Ma}$ [21], and a really dominating biotite granite suite and a quartz syenite suite of more restricted extent. The granite suite is composed of three subunits which are, from oldest to youngest: K-feldspar mega crystic medium- to coarse-grained biotite granite (main phase); mega crystic biotite microgranite with medium- to coarse grained porphyroclasts of plagioclase, K-feldspar, quartz and biotite (first sub intrusion); non-mega crystic biotite microgranite (second sub intrusion). The quartz syenite suite covers a large compositional spectrum from gabbroic cumulate rocks to hornblende-biotite quartz syenite (main phase) to alkali feldspar-hornblende granite pegmatite.

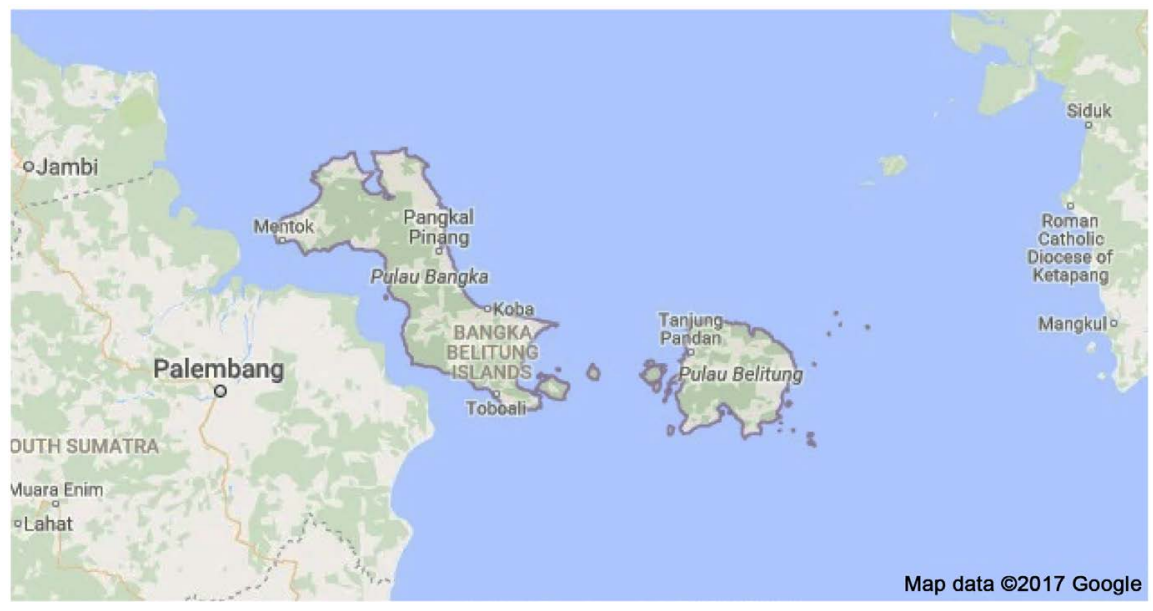

Figure 1. The geographical position of Bangka-Belitung Island, Indonesia. 


\subsection{Silica Extractions}

A $150 \mathrm{~g}$ of 325-mesh quartz sand sample was boiled in $100 \mathrm{~mL} \mathrm{HCl}$ at various concentrations, i.e. $1,3,5,7$, and $9 \mathrm{~N}$ until almost all of solution evaporated to dissolve any contaminant elements present. The treated samples were then washed out with tap water several times to eliminate the contaminants and the rest of $\mathrm{HCl}$ solution. Wet samples were transferred on a sheet of paper and dried out at $100^{\circ} \mathrm{C}$ in an oven until completely dry. A $60 \mathrm{~g}$ washed sample was then mixed with $80 \mathrm{~g} \mathrm{NaOH}$ (s) in a stainless pan and heated on stove at $330^{\circ} \mathrm{C}$ while stirred manually until melted. The melted mixture was kept stirred until it dried out. After cooling at room temperature, a $60 \mathrm{~g}$ pre-treated quartz sand was dissolved in $400 \mathrm{~mL}$ distilled water. The liquid obtained was the soluble silica $\left(\mathrm{H}_{4} \mathrm{SiO}_{4}\right)$. Silica concentration was determined by spectrophotometer. A series of similar experiment was also conducted by varying the volume of $\mathrm{HCl}$ with optimum concentration obtained previously, i.e. 100, 200, 300, and $400 \mathrm{~mL}$.

The $\mathrm{HCl}$ concentration and volume yielding the highest soluble Si was then used in the next experiment to determine the optimum volume of $\mathrm{NaOH}$ (s). A $150 \mathrm{~g}$ of 325-mesh quartz sand sample was boiled in $\mathrm{HCl}$ with optimum concentration and volume obtained previously following the above-described method and then a $60 \mathrm{~g}$ pretreated sand was mixed with different volume of $\mathrm{NaOH}$ (s), e. g. 20, 40, 60, 80, and $100 \mathrm{~g}$. As a comparison, the same experiment was carried out by replacing the quartz sand with other Si-bearing mineral, i.e. a 150-mesh natural zeolite originated from Bayah, West Java. All solid samples were subjected to XRD and SEM analyses.

\subsection{Chemical and Mineralogical Characterization}

\subsubsection{Chemical Analysis}

The mineral used was quartz type collected from Bangka-Belitung province. Quartz samples were air dried and passed through 325 mesh sieves and analyzed for the following: $\mathrm{pH}$, total carbon (spectrophotometer), nitrogen (Kjeldahl), phosphorus (spectrophotometer), potassium (Atomic Absorption Spectrophotometer, AAS), magnesium (AAS), calcium (AAS), total $\mathrm{SiO}_{2}$ (gravimetry), soluble Si (spectrophotometer), Sulphur, Zinc, aluminum trioxide, iron trioxide, manganese dioxide, and cation exchange capacity (CEC) by using [22] standard method.

\subsubsection{X-Ray Diffraction}

Random-oriented samples were analyzed by XRD using $\mathrm{Cu} \mathrm{Ka}$ radiation at 40 $\mathrm{kV}$ and $30.0 \mathrm{~mA}$ from XRD-6000 Shimadzu equipped with 1ow divergence and receiving slits and a graphite monochromator. Minerals present in the sand fraction sample were identified from random powder diffraction patterns following the procedures given by [23]. A continuous scan was applied in a horizontal scale ranging from 3 to $90^{\circ} 2 \theta$ at a scan speed of $3^{\circ} 2 \theta \mathrm{min}^{-1}$ and a sampling pitch of $0.02-2 \theta$. Calibration was carried out using a $325-$ mesh Silicon powder standard of Shimadzu containing $990.0 \mathrm{~g} \cdot \mathrm{kg}^{-1} \mathrm{SiO}_{2}$. 


\subsubsection{Electron Microscopy}

All solid material both treated and un-treated samples were examined with a Scanning Electron Microscope (SEM). The electron beam is accelerated through a high voltage $20 \mathrm{kV}$ and pass through a system of apertures and electromagnetic lenses to produce a thin beam of electrons [24]. In the early stages a material sample leveled with a special tool. After sputter coating the cast with $35 \mathrm{~nm}$ of gold-palladium (Au-Pd), electron micrographs were generated using a Jeol JSM-5310LV SEM.

\section{Result and Discussion}

\subsection{Chemical Characteristics of Bangka-Belitung Quartz Sand}

The Bangka-Belitung province and the adjacent area have been known since a long time ago as a main quart's sand-producing area in Indonesia. Selected chemical analyses in this research show that the quartz sand has alkaline reaction ( $\mathrm{pH} \mathrm{H} \mathrm{H}_{2} \mathrm{O}-8.2$ ) with the $1.2 \mathrm{~g} \cdot \mathrm{kg}^{-1} \mathrm{C}$-org, $0.3 \mathrm{~g} \cdot \mathrm{kg}^{-1}$ total $\mathrm{N}, 30.1 \mathrm{mg} \cdot \mathrm{kg}^{-1}$ $\mathrm{P}_{2} \mathrm{O}_{5}, 6.1 \mathrm{mg} \cdot \mathrm{kg}^{-1} \mathrm{~K}_{2} \mathrm{O}, 0.05 \mathrm{mg} \cdot \mathrm{kg}^{-1} \mathrm{CaO},<0.01 \mathrm{mg} \cdot \mathrm{kg}^{-1} \mathrm{MgO}, 971-991 \mathrm{~g} \cdot \mathrm{kg}^{-1}$ total $\mathrm{SiO}_{2}, 0.90 \mathrm{mg} \cdot \mathrm{kg}^{-1} \mathrm{H}_{4} \mathrm{SiO}_{4}, 86.0 \mathrm{mg} \cdot \mathrm{kg}^{-1} \mathrm{~S}, 53.2 \mathrm{mg} \cdot \mathrm{kg}^{-1} \mathrm{Zn}, 1.7 \mathrm{~g} \cdot \mathrm{kg}^{-1} \mathrm{Al}_{2} \mathrm{O}_{3}$, $0.6 \mathrm{~g} \cdot \mathrm{kg}^{-1} \mathrm{Fe}_{2} \mathrm{O}_{3},<0.1 \mathrm{~g} \cdot \mathrm{kg}^{-1} \mathrm{MnO}_{2}$, and CEC $1.98 \mathrm{cmol}^{+} \cdot \mathrm{kg}^{-1}$. The results of the analysis of the levels of silica in this study support the analysis by [25]. Reference to [23], based on the diffractogram silica sand samples analysis is dominated by the initial mineral quartz $\left(\mathrm{SiO}_{2}\right)$ and this is supported by the XRF data showing that silica sand obtained a good quality with a cadre of over $980 \mathrm{~g} \cdot \mathrm{kg}^{-1}$ total $\mathrm{SiO}_{2}$. The result of this analysis show that impurities usually present in the silica sand are free and coated iron oxides, aluminum, and smaller amounts of magnesium, potassium and calcium minerals. The iron, being the most detrimental impurity, can be reduced by a number of physical, physico-chemical or chemical methods, the most appropriate method depends on the mineralogical forms and distribution of iron in the ore [26] [27]. According to [28] [29] [30], upgrading of silica sand requires partial removal of iron, and other minerals which are detrimental to its end use. While much of the liberated impurities can be reduced or removed by physical operations such as size separation (screening), gravity separation (spiral concentration), magnetic separation etc. [31] [32] [33] [34]. Sometimes, physico-chemical (flotation) or even chemical methods (leaching etc.) are to be adopted for the effective removal of iron which may be in intimate association with the mineral quite often superficially [35] [36].

\subsection{Optimization of Silica Extraction Condition}

In this study water-soluble $\mathrm{Si}$ (OSA) was obtained by washing the quartz sand with $\mathrm{HCl}$ prior to $\mathrm{NaOH}$ extraction. To determine the most optimum conditions for extraction, a series of concentration and volume of $\mathrm{HCl}$ was tested to obtain OSA. Data in Figure 2 indicate that $\mathrm{HCl}$ concentrations are quadratically related with OSA obtained $\left(\mathrm{R}^{2}=0.72^{\star}\right)$, with optimum concentration at $3.4 \mathrm{~N}$. On the other experiment, the volume of $\mathrm{HCl} 5 \mathrm{~N}$ was also found quadratically correlated 


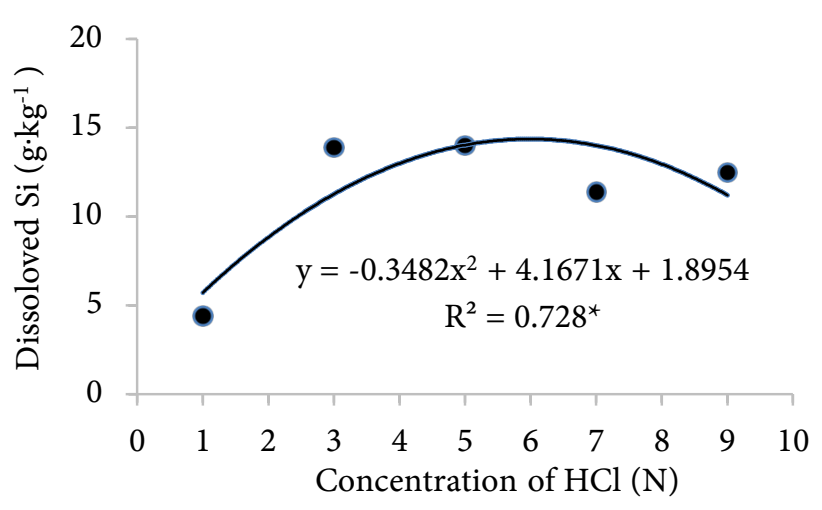

Figure 2. Correlation between $\mathrm{HCl}$ concentration with OSA extracted from acid-pre-washed quartz sand.

with OSA extracted $\left(\mathrm{R}^{2}=0.56^{*}\right)$ reaching the optimum volume at $300 \mathrm{~mL}$ (Figure 3). By employing both optimum values of $\mathrm{HCl}$ solution on $\mathrm{NaOH}$ (s) extraction experiment, it shown in Figure 4 that extracted OSA is linearly correlated with the quantity of $\mathrm{NaOH}$ (s) from 20 to $100 \mathrm{~g} \mathrm{NaOH}$ tested $\left(\mathrm{R}^{2}=0.99^{* *}\right)$.

The results of this experiment indicate that the $\mathrm{HCl}$ pre-washing is important to eliminate the other element contaminants of the Si-bearing materials. The use of $\mathrm{HCl}-\mathrm{NaOH}$ extraction technique on quartz sand yielded as high as $183 \mathrm{~g} \cdot \mathrm{kg}^{-1}$ OSA up to $100 \mathrm{~g} \mathrm{NaOH}$ (s). Many researches have been reported relating to extraction of silica. Reference [37] synthesized of silica particles from rice straw waste by using $\mathrm{KCl}$ and $\mathrm{KOH}$, while [38] produce pure silica from rice hull ash by using $1 \mathrm{~N} \mathrm{HCl}$ and $60 \mathrm{~mL} \mathrm{NaOH}$. It is assumed that the efficiency of extraction using this double acid-base extraction to some extent depending on the Si-bearing material. Our data show that by using other Si-bearing mineral, i.e. Bayah natural zeolite, the optimum level of $\mathrm{NaOH}$ (s) quantity was $80 \mathrm{~g}$ to obtain its highest water-soluble $\mathrm{Si}$, which is only $104.2 \mathrm{~g} \cdot \mathrm{kg}^{-1}$ (Figure 5). Improvement of extractable Si due to pre-treatment on the quartz sample is shown in Table 1. An acid-prewashed sand and its origin were insoluble in water, whereas the treatment with heated $\mathrm{NaOH}$ (s) on the former improved significantly the water solubility up to almost $800 \mathrm{~g} \cdot \mathrm{kg}^{-1}$. Extractable Si of acid pre-washed sample was considerably low $\left(0.067+/-0.007 \mathrm{~g} \cdot \mathrm{kg}^{-1}\right)$, while the addition with heated $\mathrm{NaOH}(\mathrm{s})$ yielded significantly high values $\left(119.835+/-2.165 \mathrm{~g} \cdot \mathrm{kg}^{-1}\right)$.

\subsection{Mineralogical Evidences}

In natural condition, Si mineral has a strong crystalline structure. The use of strong acid wash and strong base extraction will alter the crystallinity of the mineral and as a consequence releasing more Si into solution. Figure 6 shows the XRDs indicating that the addition of $\mathrm{HCl}$ and $\mathrm{NaOH}(\mathrm{s})$, respectively, yielded in drastically decreasing of quartz peak intensity at $2 \theta$ of $26.5^{\circ}$ and other minerals like crystobalite and feldspar. The composition of minerals was suggested to be dominated by amorphous Si material. The evidences of peak bumps appeared at between $10^{\circ}$ and $20^{\circ} 2 \theta$ is presumably due to the effect of extracting 


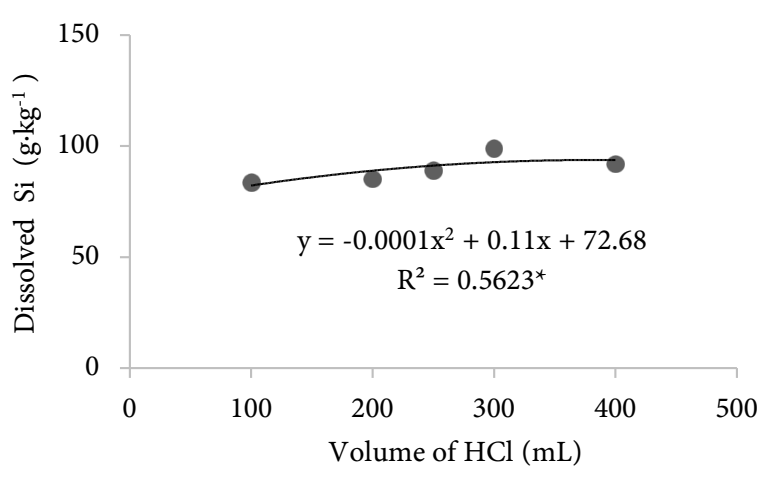

Figure 3. Correlation between volume of $5 \mathrm{~N} \mathrm{HCl}$ with OSA extracted from acid-pre-washed quartz sand.

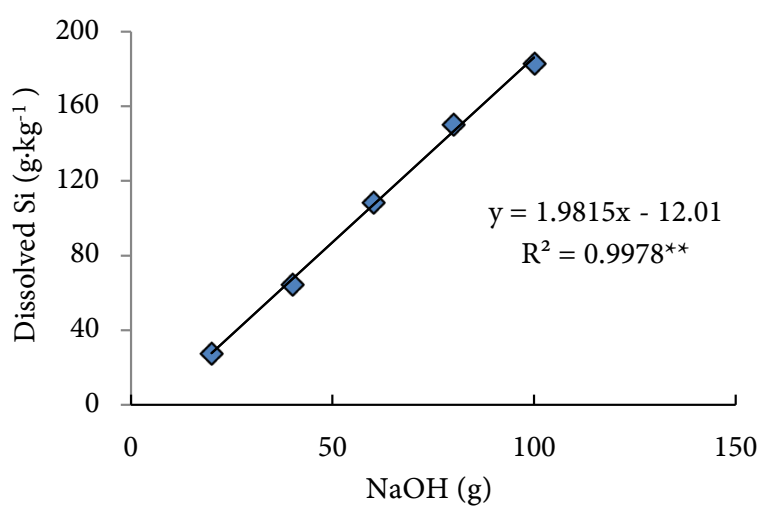

Figure 4. Correlation between quantity of $\mathrm{NaOH}$ (s) with OSA extracted from acid-pre-washed quartz sand.

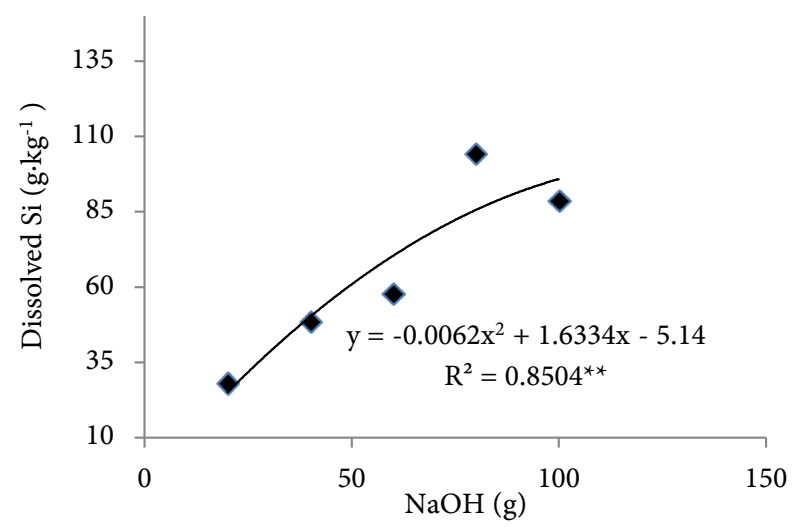

Figure 5. Correlation between quantity of $\mathrm{NaOH}$ (s) with OSA extracted from acid-pre-washed zeolite.

Table 1. Effects of acid-base pretreatments of quartz sand on its water solubilization and extractable Si.

\begin{tabular}{ccc}
\hline Quartz Sand Treatment & Solubility in $\mathrm{H}_{2} \mathrm{O}(\%)$ & Extractable Si (\%) \\
\hline Untreated (origin) & 0 & \\
HCl-washed and boiled (A) & 0 & $0.0060-0.0073(0.0067 \pm 0.0007)$ \\
$\mathrm{A}+\mathrm{NaOH}(\mathrm{s})$-mixed and heated & 79.5 & $11.7670-12.2000(11.9835 \pm 0.2165)$ \\
\hline
\end{tabular}




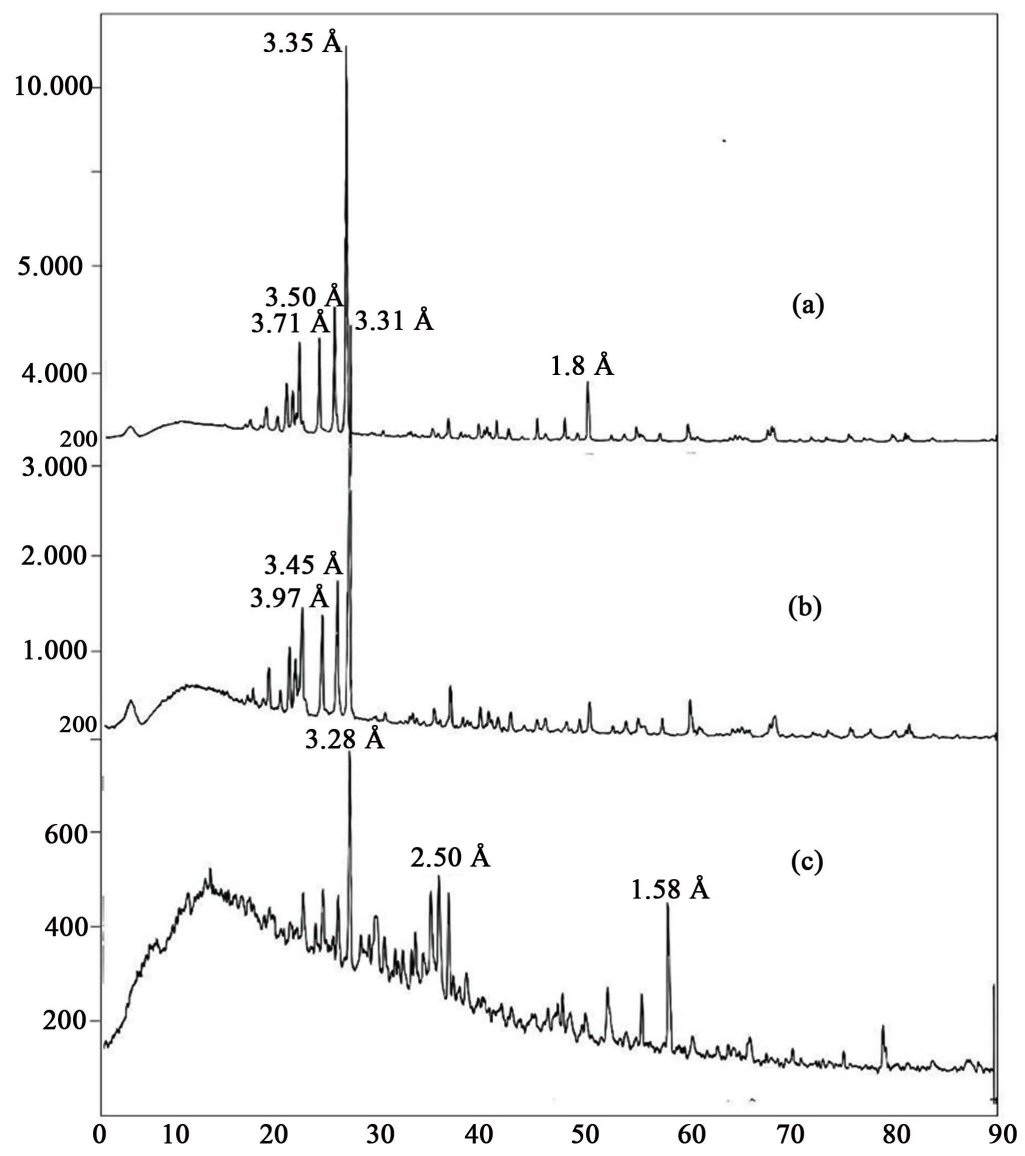

Figure 6. X-ray diffractograms of original Belitung quartz sand (a); $\mathrm{HCl}$ pre-washed (b); $\mathrm{NaOH}(\mathrm{s})$ reacted (c).

chemicals (i.e. $\mathrm{HCl}$ ) which removed $\mathrm{Fe}$-and $\mathrm{Al}$ oxides/hydroxides and revealed other contaminant minerals' peaks (Figure 6(b)). The intensity of these bumping peaks was strengthened after the sample treated with $\mathrm{NaOH}$ (Figure 6(c)). It leads to an assumption that a new mineral group (i.e. zeolites) was synthesized when $\mathrm{Si}$ reacted with hot $\mathrm{NaOH}$ as reported by some researchers previously [39] [40] [41]. Based on energy dispersive X-ray spectroscopy data the $\mathrm{HCl}-\mathrm{NaOH}$ treated sample has mass composition of C (6.1\%), O (55.4\%), Na (29.3\%), and Si (9.3\%) with atomic distribution 9.1, 62.1, 22.9, and 6.0\% of $\mathrm{C}, \mathrm{O}, \mathrm{Na}$, and $\mathrm{Si}$, respectively. The liquid obtained by dissolving of $150 \mathrm{~g}$ of $\mathrm{HCl}-\mathrm{NaOH}(\mathrm{s})$ treated sand with $400 \mathrm{~mL}$ of distilled $\mathrm{H}_{2} \mathrm{O}$ was dominated by amorphous Si material presumably OSA. This assumption was supported by the evidences obtained from SEM analysis (Figure 7).

The SEM image of the original sample of quartz (a) shows the dominance of large crystals, whereas by acid treatment (b), some quartz dissolved into smaller crystals, and by adding $\mathrm{NaOH}$ (c) alot of quartz dissolved to be an amorphous material and small crystalline minerals which can be shown by the image in an oval and a square sign respectively. On the other hand, it shows in Figure 8 that the appearance of water-soluble $\mathrm{NaOH}$ pre-treated quartz sand resembles those of $\mathrm{Na}_{2} \mathrm{SiO}_{3}$ crystallite structure. 


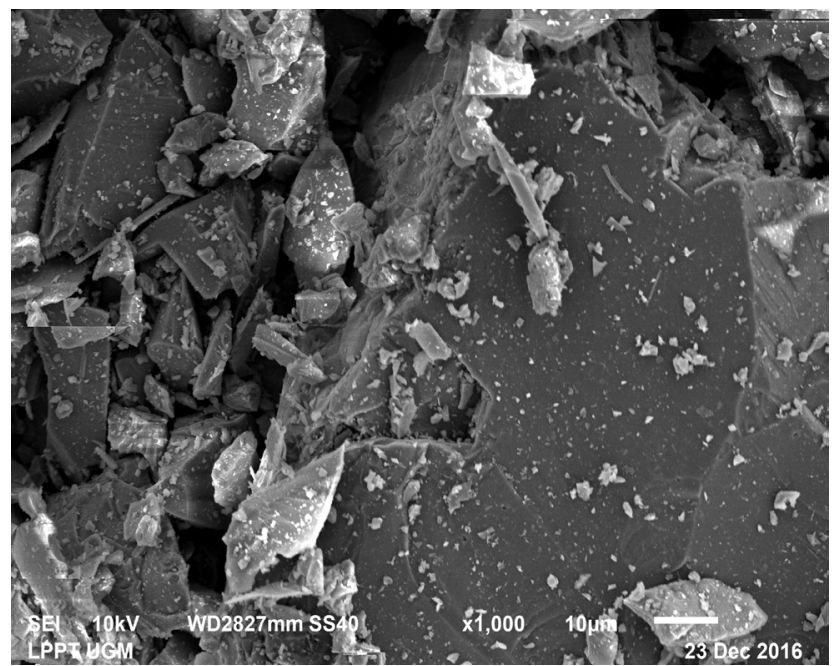

(a)

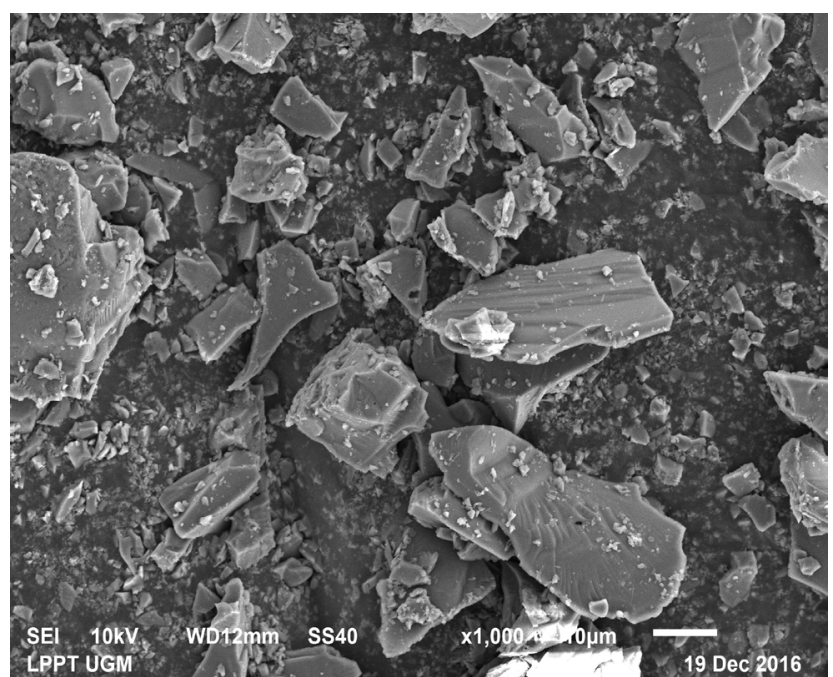

(b)

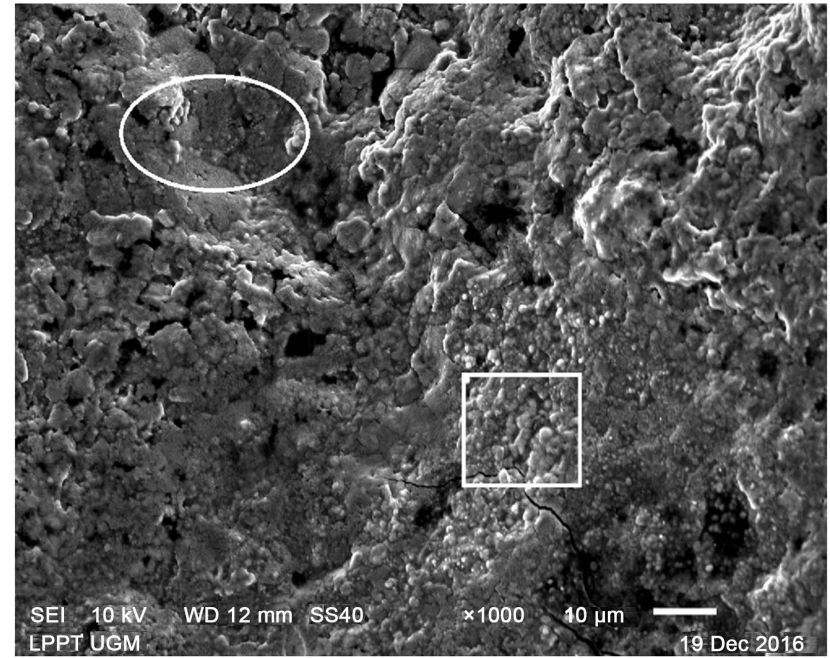

(c)

Figure 7. Scanning-electron microscopy (SEM) micrographs of original quartz sand (a); $\mathrm{HCl}$ pre-washed (b); $\mathrm{NaOH}$ (s) reacted (c). 


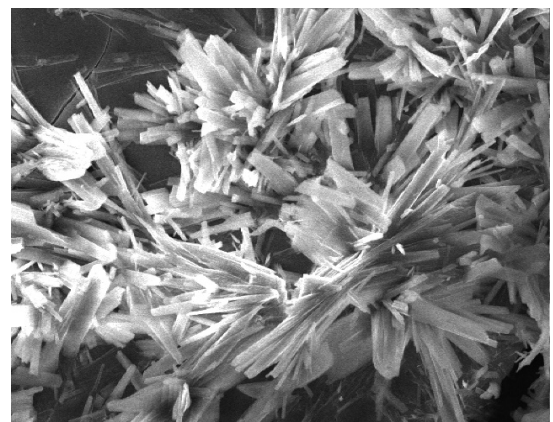

(a)

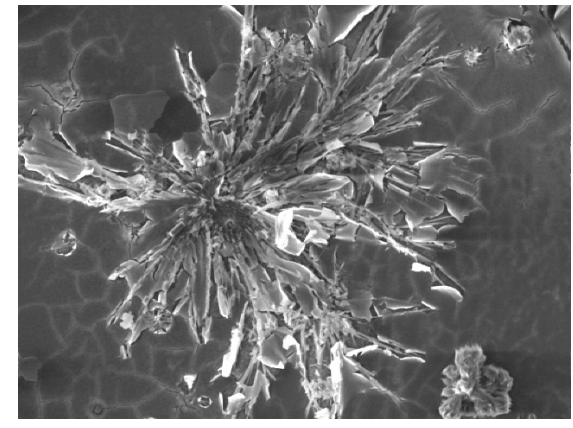

(b)

Figure 8. Scanning-electron microscopy (SEM) micrographs of water-soluble $\mathrm{NaOH}$ pre-treated quartz sand (a); and $\mathrm{Na}_{2} \mathrm{SiO}_{3}$, (sodium metasilicate) (b).

\section{Conclusion}

The results from this study show that by using $\mathrm{HCl}-\mathrm{NaOH}$ (s) extraction technique on a quartz sand ( $970-990 \mathrm{~g} \cdot \mathrm{kg}^{-1}$ total $\mathrm{SiO}_{2}$ ) could yield considerably high concentration of OSA suitable for silica liquid fertilizer formula. Optimum OSA yield $\left(183 \mathrm{~g} \cdot \mathrm{kg}^{-1}\right)$ was obtained from this material by employing $300 \mathrm{~mL} \mathrm{HCl} 3.4$ $\mathrm{N}$, reacted with $80 \mathrm{~g} \mathrm{NaOH}(\mathrm{s})$, and diluted into $400 \mathrm{~mL}$ distilled water. Considering the abundantly available of the raw material, an efficient production cost for silica liquid fertilizer could be achieved.

\section{Acknowledgements}

The authors wish to thank to the Indonesia Estate Crop Fund for Oil Palm, for valuable supports in funding this research (Contract No. PRJ-52/DPKS/2016).

\section{References}

[1] Guntzer, F., Keller, C., Poulton, P.R., McGrath, S.P. and Meunier, J.D. (2012) Long Term Removal of Wheat Straw Decreases Soil Amorphous Silica at Broadbalk, Rothamsted. Plant Soil, 352, 173-184. https://doi.org/10.1007/s11104-011-0987-4

[2] Rizwan, M., Ali, S., Ibrahim, M., Farid, M., Adrees, M., Bharwana, S.A., Rehman, M.Z., Qayyum, M.F. and Abbas, F. (2015) Mechanisms of Silicon-Mediated Alleviation of Drought and Salt Stress in Plants: A Review. Environmental Science and Pollution Research, 22, 15416-15431. https://doi.org/10.1007/s11356-015-5305-x

[3] Currie, H.A. and Perry, C.C. (2007) Silica in Plants: Biological, Biochemical and Chemical Studies. Annals of Botany, 100, 1383-1389.

https://doi.org/10.1093/aob/mcm247

[4] Sacala, E. (2009) Role of Silicon in Plant Resistance to Water Stress. Journal of Elementology, 14, 619-630. https://doi.org/10.5601/jelem.2009.14.3.20

[5] Balakhnina, T. and Borkowska, A. (2013) Effects of Silicon on Plant Resistance to Environmental Stresses: Review. International Agrophysics, 27, 225-232. https://doi.org/10.2478/v10247-012-0089-4

[6] Chidrawar, J.N.S., Thorat, V., Shah, P. and Rao, V. (2014) Ortho Silicic Acid (OSA) Based Formulations Facilitates Improvement in Plant Growth and Development. 6th International Silicon in Agriculture Conference, Stockholm, 26-30 August 2014.

[7] Edward, B. (2014) Silicon Solutions. Sestante Edizioni, Bergamo, 184 p. 
[8] Heckman, J. (2013) Silicon: A Beneficial Substance. Better Crops, 97, 14-16.

[9] Farooq, M., Wahid, A., Kobayashi, N., Fujita, D. and Basra, S.M.A. (2009) Plant Drought Stress: Effects, Mechanisms and Management. Agronomy for Sustainable Development, 29, 185-212. https://doi.org/10.1051/agro:2008021

[10] Ashraf, M. and Harris, P.J.C. (2013) Photosynthesis under Stressful Environments: An Overview. Photosynthetica, 51, 163-190.

https://doi.org/10.1007/s11099-013-0021-6

[11] Zhu, J., Liang, Y.C., Ding, Y.F. and Li, Z.J. (2006) Effect of Silicon on Photosynthesis and Its Related Physiological Parameters in Two Winter Wheat Cultivars under Cold Stress. Scientia Agricultura Sinica, 39, 1780-1788.

[12] Chanchal, M.C.H., Kapoor, R.T. and Ganjewala, D. (2016) Alleviation of Abiotic and Biotic Stresses in Plants by Silicon Supplementation. Scientia Agriculturae, 13, 59-73.

[13] Sommer, M., Kaczorek, D., Kuzyakov, Y. and Breuer, T. (2006) Silicon Pools and Fluxes in Soils and Landscapes: A Review. Journal of Plant Nutrition and Soil Science, 169, 310-329. https://doi.org/10.1002/jpln.200521981

[14] Diedrich, T., Dybowska, A., Schott, J., Valsami-Jones, E. and Oelkers, E.H. (2012) The Dissolution Rates of $\mathrm{SiO}_{2}$ Nanoparticles as a Function of Particle Size. Environmental Science \& Technology, 46, 4909-4915. https://doi.org/10.1021/es2045053

[15] Sauer, D., Saccone, L., Conley, D.J., Herrmann, L. and Sommer, M. (2006) Review of Methodologies for Extracting Plant-Available and Amorphous Si from Soils and Aquatic Sediments. Biogeochemistry, 80, 89-108. https://doi.org/10.1007/s10533-005-5879-3

[16] Conley, D.J., Sommer, M. and Meunier, D.J. (2006) Silicon in the Terrestrial Biogeosphere. In: Ittekot, V., Humborg, C. and Garnier, J., Eds., Land-Ocean Nutrient Fluxes. Silica Cycle, SCOPE Series 66, 13-28.

[17] McKeague, J.A. and Cline, M.G. (1963) Silica in Soil Solutions. I. The Form and Concentration of Dissolved Silica in Aqueous Extracts of Some Soils. Canadian Journal of Soil Science, 43, 70-82. https://doi.org/10.4141/cjss63-010

[18] Cornelis, J.T., Titeux, H., Ranger, R. and Delvaux, B. (2011) Identification and Distribution of the Readily Soluble Silicon Pool in a Temperate Forest Soil below Three Distinct Tree Species. Plant and Soil, 342, 369-378.

https://doi.org/10.1007/s11104-010-0702-x

[19] Rohendi, E. and Aryanto, N.C.D. (2012) Seafloor Sediment Characteristics and Heavy Mineral Occurrences at Betumpak Cape and Adjacent Area, Bangka Strait, Bangka-Belitung Province. Bulletin of the Marine Geology, 27, 7-18.

[20] Baharuddin and Sidarto (1995) Peta Geologi Bersistem, Lembar Belitung, Skala 1:250.000, Pusat Penelitian dan Pengembangan Geologi, Bandung. [Geologic Map of the System, Belitung Plate, Scale 1: 250.000. Geological Research and Development Centre, Bandung.]

[21] Lehman, B. and Harmanto (1990) Large-Scale Tin Depletion in the Tanjungpandan Tin Granite, Belitung Island, Indonesia. Society of Economic Geologists.

[22] SNI 15-0346-1989 (1989) Pasir kuarsa untuk pembuatan gelas tak berwarna, Mutu dan cara uji. [Quartz Sand for the Manufacture of Colorless Glass, Quality and Test Methods.] National Standardization Agency of Indonesia.

[23] Brindley, G.W. and Brown, G. (1980) Crystal Structures of Clay Minerals and Their X-Ray Identification. Mineralogical Society, Monograph No. 5, London, 495 p.

[24] Zhou, W., Apkarian, R., Wang, Z.L. and Joy, D. (2006) Fundamentals of Scanning Electron Microscopy (SEM). In: Zhou, W. and Wang, Z.L., Eds., Scanning Micro- 
scopy for Nanotechnology Techniques and Applications, Springer Science Business Media, New York.

[25] Wahyudi, A., Nurasid, T. and Rochani, S. (2012) Preparation of Nanoparticle Silica from Silica Sand and Quartzite by Ultrafine Grinding. International Conference on Chemical and Material Engineering, 12-13 September 2012, 1-7.

[26] Ay, N. and Arica, E. (2000) Refining Istanbul's Silica Sand. The American Ceramic Society Bulletin, August, 89-91.

[27] Wills, B.A. (1998) Mineral Processing Technology. Pergamon Press, New York.

[28] Sundararajan, M., Ramaswamy, S. and Raghavan, P. (2009) Evaluation for the Beneficiability of White Silica Sands from the Overburden of Lignite Mine Situated in Rajpardi District of Gujarat, India. Journal of Minerals and Materials Characterization and Engineering, 8, 701-713. https://doi.org/10.4236/jmmce.2009.89061

[29] Mohamed, S. and Mostafa, R.A. (2016) Enhancing the Technical Qualifications of Egyptian White sand using Acid Leaching; Response Surface Analysis and Optimization. Mineral Processing and Extractive Metallurgy, 1, 33-40.

[30] Huang, H., Li, J., Li, X. and Zhang, Z. (2013) Iron Removal from Extremely Fine Quartz and Its Kinetics. Separation and Purification Technology, 108, 45-50.

[31] Du, F., Li, J.S., Li, X.X. and Zhang, Z.Z. (2011) Improvement of Iron Removal from Silica sand using Ultra-Assisted Oxalic Acid. Ultrasonics Sonochemistry, 18, 389-393.

[32] Veglio, F., Passariello, B. and Abbruzzese, C. (1999) Iron Removal Process for High-Purity Silica Sands Production by Oxalic Acid Leaching. Industrial \& Engineering Chemistry Research, 38, 4443-4448. https://doi.org/10.1021/ie990156b

[33] Dal-Martello, E., Bernardis, S., Larsen, D.G., Sabatino, M. and Arnberg, L. (2012) Electrical Fragmentation as a Novel Route for the Refinement of Quartz Raw Materials for Trace Mineral Impurities. Powder Technology, 224, 209-216.

[34] Zhang, Z., Li, J., Li, X., Huang, H., Zhou, L. and Xiong, T. (2012) High Efficiency Iron Removal from Quartz Sand using Phosphoric Acid. International Journal of Mineral Processing, 114, 30-34.

[35] Veglio, F., Passariello, B., Barbaro, M., Plescia, P. and Marabini, A.M. (1998) Drum Leaching Tests in Iron Removal from Quartz using Oxalic and Sulphuric Acids. International Journal of Mineral Processing, 54, 183-186.

[36] Hassan, H. (2014) Enrichment of Silica Sand Ore by Cyclojet Flotation Cell. Separation Science and Technology, 49, 1623-1632.

https://doi.org/10.1080/01496395.2014.893357

[37] Nandiyanto, A.B.D., Rahman, T., Fadhlulloh, M.A., Abdullah, A.G., Hamidah, I. and Mulyanti, B. (2016) Synthesis of Silica Particles from Rice Straw Waste using a Simple Extraction Method. International Conference on Innovation in Engineering and Vocational Education, 1-9. https://doi.org/10.1088/1757-899X/128/1/012040

[38] Kalapathy, U., Proctor, A., Shultz, J., Proctor, A. and Shultz, J. (2000) A Simple Method for Production of Pure Silica from Rice Hull Ash. Bioresource Technology, 73, 257-262.

[39] Bergaut, V. and Singer, A. (1996) High Capacity Cation Exchanger by Hydrothermal Zeolitization of Coal Fly Ash. Applied Clay Science, 10, 369-378.

[40] Inada, M., Iguchi, Y., Enomoto, N. and Hojo, J. (2005) Synthesis of Zeolite from Coal Fly Ashes with Different Silica-Alumina Composition. Fuel, 84, 299-304.

[41] Marutani, K., Shiono, T. and Okamoto, Y. (2013) Synthesis of Consolidated Zeolite from Rice Husk Ash. Journal of the Society of Materials Science, Japan, 62, 575-578. https://doi.org/10.2472/jsms.62.575 